\title{
Synovial cysts of the lumbar spine
}

\section{Torbiele synowialne odcinka lędźwiowego kręgosłupa}

\author{
Roman Jankowski', Janusz Szymaś2', Stanisław Nowak', Ryszard Żukiel', Bartosz Sokół', Włodzimierz Paprzycki \\ 1 Katedra i Klinika Neurochirurgii i Neurotraumatologii, Uniwersytet Medyczny im. Karola Marcinkowskiego w Poznaniu \\ 2 Pracownia Patomorfologii Neurochirurgicznej Katedry Patomorfologii Klinicznej, Uniwersytet Medyczny im. Karola Marcinkowskiego w Poznaniu \\ 3Zakład Neuroradiologii, Uniwersytet Medyczny im. Karola Marcinkowskiego w Poznaniu
}

Neurologia i Neurochirurgia Polska 2012; 46, 5: 456-461

DOI: 10.5114/ninp.2012.31356

\begin{abstract}
Background and purpose: Synovial cysts of the spine occur most frequently in the lumbosacral region. Methods of treatment vary, but in cases of chronic pain or neurological deficits surgical intervention is undertaken. The aim of this paper is to present indications, surgical technique and efficacy of surgical treatment in patients with synovial cyst of the spinal canal.
\end{abstract}

Material and methods: The retrospective analysis included 11 patients, aged from 47 to 72 years, treated at the Department of Neurosurgery and Neurotraumatology, Poznan University of Medical Sciences, between 2004 and 2009 The length of medical history ranged from 2 months to 6 years. Conservative treatment applied before surgery was not effective. Neurological examination revealed unilateral or bilateral sciatica, superficial sensory disturbance or lower limb paresis.

Results: Synovial cysts were located mainly at the L4-L5 level (9 cases). Magnetic resonance imaging (MRI) of the spine was performed in all patients and showed the cystic lesion attached to the intervertebral joint. Surgical treatment consisted of a unilateral fenestration using microsurgical techniques in most cases. Back pain relief was observed in 9 cases. In 10 patients, symptoms of sciatica disappeared. Neurological deficits disappeared in 5 patients.

Conclusions: Surgical treatment of spinal synovial cysts is safe, effective and ensures a long-lasting effect. Surgical treat-

\section{Streszczenie}

Cel pracy: Torbiele synowialne kręgosłupa występują najczęściej w odcinku lędźwiowo-krzyżowym. Opracowano zróżnicowane sposoby leczenia tych zmian zwyrodnieniowych, jednak w przypadkach przewlekłego bólu lub wystąpienia neurologicznych objawów ubytkowych zaleca się interwencję chirurgiczną. Celem pracy jest przedstawienie wskazań, techniki operacyjnej i skuteczności leczenia operacyjnego chorych z torbielą synowialną kanału kręgowego.

Materiał i metody: Retrospektywną analizą kliniczną objęto 11 pacjentów, w wieku od 47 do 72 lat, leczonych w Katedrze i Klinice Neurochirurgii i Neurotraumatologii UM w Poznaniu w latach 2004-2009. Długość wywiadu chorobowego wahała się od 2 miesięcy do 6 lat. Leczenie zachowawcze stosowane przed leczeniem operacyjnym nie dawało poprawy. W badaniu neurologicznym stwierdzono jednostronną lub obustronną rwę kulszową, zaburzenia czucia powierzchniowego bądź niedowłady kończyn dolnych.

Wyniki: Torbiel umiejscawiała się najczęściej na poziomie L4-L5 (9 przypadków). Badanie kręgosłupa za pomocą rezonansu magnetycznego (RM) zostało wykonane u wszystkich pacjentów i wykazało zmianę o charakterze torbielowatym, która była połączona ze stawem międzykręgowym. Leczenie operacyjne polegało w większości przypadków na jednostronnej fenestracji więzadła żółtego $\mathrm{z}$ wykorzystaniem techniki mikrochirurgicznej. Ustąpienie dolegliwości bólowych kręgosłupa zaobserwowano w 9 przypadkach. U 10 chorych

Correspondence address: dr hab. Roman Jankowski, Katedra i Klinika Neurochirurgii i Neurotraumatologii, Uniwersytet Medyczny im. Karola Marcinkowskiego w Poznaniu, ul. Przybyszewskiego 49, 60-355 Poznań, Polska, phone: +48 6186914 32, e-mail: klinikanch@op.pl

Received: 26.01.2011; accepted: 14.02.2012 
ment is indicated in patients in whom the clinical symptoms correlate with the presence of synovial cyst in imaging studies and do not resolve after conservative treatment.

Key words: synovial cyst, lumbar spine, surgical management.

\section{Introduction}

Synovial cysts of the spinal canal cause direct compression on the nervous structures within the spinal canal. They are most common in the lumbosacral spine, but can be found in both the cervical and thoracic spine [1-6]. The incidence of synovial cysts varies from $0.1 \%$ to $0.8 \%$ in patients who have undergone surgery for various spinal disorders [7]. Cysts seldom result in chronic back pain and sciatica. The origins of synovial cysts remain controversial. The role of either injury or inflammation as pathognomonic factors is still under dispute. Similarly, disagreement regarding treatment modalities exists. Various modes of conservative treatment have been proposed, but chronic pain or neurological deficits require surgical treatment $[2,7]$.

The aim of the study is to present surgical technique and the efficacy of surgical treatment of patients with spinal canal synovial cysts.

\section{Material and methods}

Our cohort included 11 patients ( 6 women and 5 men) aged 47 to 72 years (mean: 59 years) who were treated surgically for lumbar spine synovial cysts between 2004 and 2009 in the Department of Neurosurgery and Neurotraumatology of the Medical University of Poznan. Synovial cysts were most common in the sixth decade of life ( 6 out of 11 patients).

Anamnesis varied from 2 months to 6 years; 4 patients were treated conservatively for more than 2 years. Four patients reported an acute onset of the symptoms while the remaining 7 patients presented with slowly progressive symptoms. A single patient reported pain occurrence after spinal injury (immediately after a car accident) while all the others had spontaneous pain occurrence. Patients complained of persistent lumbosacral pain that escalated with a change of position. Pain inten- ustąpiły objawy rwy kulszowej. Ubytkowe objawy neurologiczne wycofały się u 5 pacjentów.

Wnioski: Leczenie chirurgiczne torbieli synowialnych kręgosłupa jest metodą bezpieczną, efektywną i zapewniającą trwały efekt. Do leczenia operacyjnego kwalifikują się chorzy, u których objawy kliniczne korelują z obecnością torbieli w badaniach obrazowych i nie ustępują po leczeniu zachowawczym.

Słowa kluczowe: torbiel synowialna, odcinek lędźwiowy kręgosłupa, leczenie chirurgiczne.

sity diminished in a supine position. Five patients reported pain aggravation at night. Pain radiated to lower extremities in all of the patients.

Prior to surgery, all the patients were treated pharmacologically on top of which 9 underwent physiotherapy. In one patient, a cyst was punctured and steroids were injected into the cyst under computed tomography (CT) guidance. No positive effects were found during 3 weeks follow-up while control magnetic resonance imaging (MRI) showed no cyst regression.

Preoperative clinical examination revealed sciatica unilateral in 9 and bilateral in 2 patients. Neurological deficits were found in 6 patients. All of them reported hypoesthesia, five of them foot paresis and one foot paralysis.

Anteroposterior, lateral and functional X-rays enabled evaluation of degenerative changes and spine stability. First degree degenerative spondylolisthesis was found in one patient. MRI and CT exams facilitated final diagnosis (Fig. 1).

A posterior approach was selected for surgery. The initial skin incision ( 3 to $4 \mathrm{~cm}$ long) was performed over spinous processes, then, after fascia incision and paravertebral muscles dissection, the level of the synovial cyst was confirmed with intraoperative X-rays. The subsequent stages of the surgery were performed under a microscope with 8 to 16 magnifications. We found hypertrophy of facet joints in 6 patients. We were able to visualize synovial cyst upon ligamentum flavum dissection followed by fenestration enlargement with partial resection of the superior-medial part of the facet in 8 patients. In 2 cases, we were forced to enlarge the operative approach owing to the narrow space between arches, invaginated ligamentum flavum and enlarged facet joint. These patients had hemilaminectomy performed in order to ensure an adequate approach to the spinal canal. A cyst was adjacent to the ligamentum flavum in one case; conversely, it was adjacent to facet 

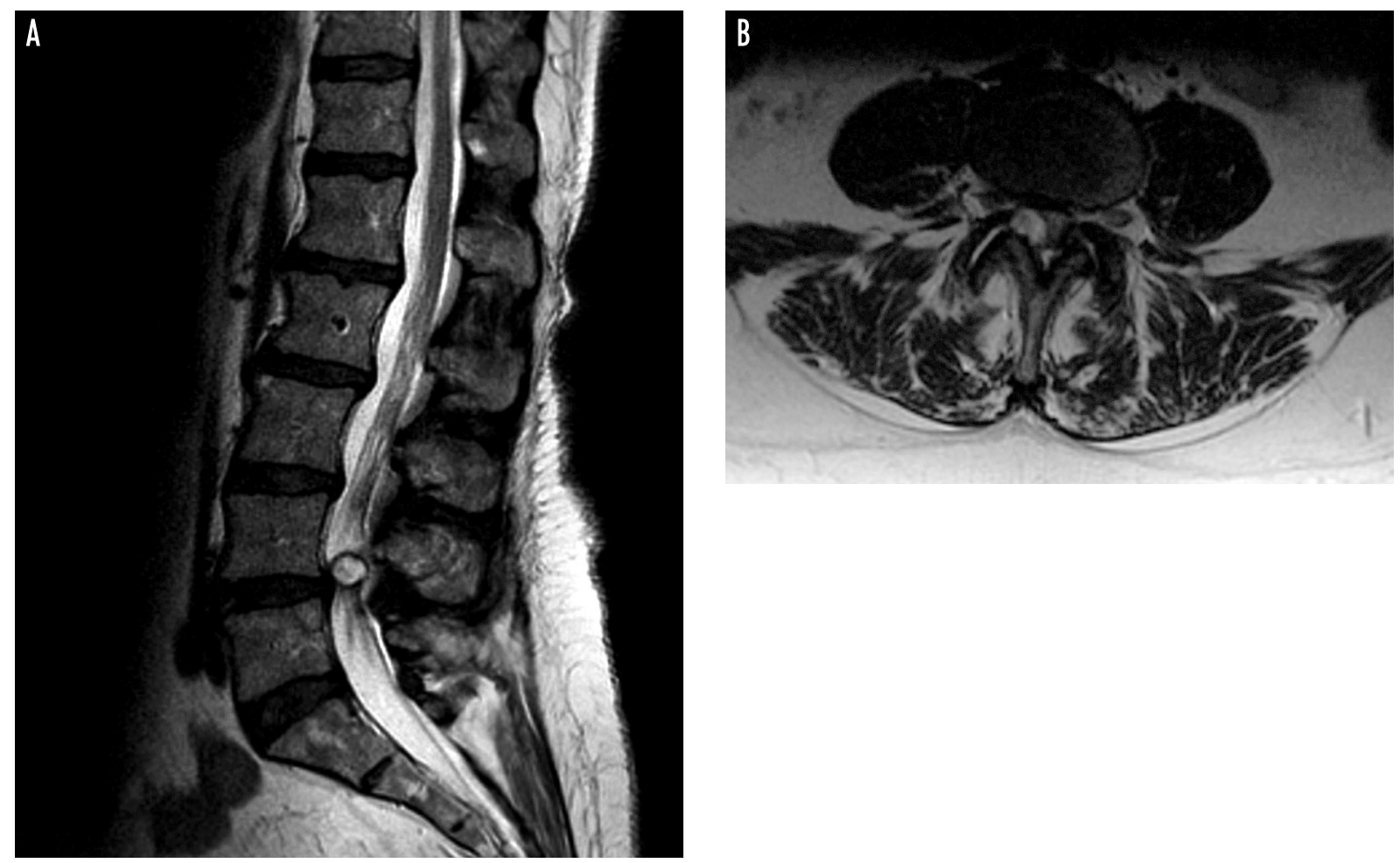

Fig. 1. A 63-year-old female patient. T2-weighted images of the lumbosacral spine in sagittal (A) and axial (B) planes reveal synovial cyst at L4-L5 level

joints in all other patients. All cysts were solid and offwhite in color. Their sizes varied from 5 to $23 \mathrm{~mm}$. Synovial cysts were located within the spinal canal at the level of the spinal root's origin (lateral recess of the spinal canal). The spinal root and dura were usually displaced medially. The cyst wall was easily dissectible from the dura, which facilitated its complete removal along with a full release of the compression of spinal canal structures. None of the patients suffered from injury of the facet joint content or spinal instability.

A patient with degenerative spondylolisthesis underwent posterior lumbar interbody fusion after cyst removal.

\section{Results}

Plain X-rays in all our patients revealed various degrees of degenerative changes: narrowing of the intervertebral space, osteophytosis, and facet joints hypertrophy. Functional X-rays showed no signs of instability in any of the patients.

Spinal CT revealed clearly demarcated, low-density lesions in the epidural space of the spinal canal usually at the facet level in 6 patients. Calcifications on the margins and gas within were found in 2 cases. MRI exami- nations were performed in all of the patients and showed cystic lesions adjacent to the facet joints. The cyst resulted in compression and dislocation of the dural sac and spinal root. Synovial cyst content was hypointense in T1-weighted images and hyperintense in T2-weighted images.

The most common location of synovial cyst (9 cases) was the L4-L5 level. Single cases of lesions of L3-L4 and L5-S1 levels were also found.

Only patients whose clinical symptoms rigorously correlated with spinal MRI results were qualified for surgery.

Histological examination disclosed synovial cyst tissue with a lumen lined with mucous membrane. Not all of the pieces of the cyst allowed us to track the continuity of the epithelium, though. Epithelial cells were often flattened owing to the compression from the mucous content of the cyst. Mucous membrane in some of the cases formed villi that bulged into the lumen of the cyst. Fibrin was often found on their surface or within, forming recesses. The synovial cyst wall was thick, formed by cell-rich, fibrous connective tissue. Foci of mucous degeneration were sometimes present. Chronic inflammation could often be found both within the cyst wall and in its vicinity. Small foci of metaplastic cartilaginous 

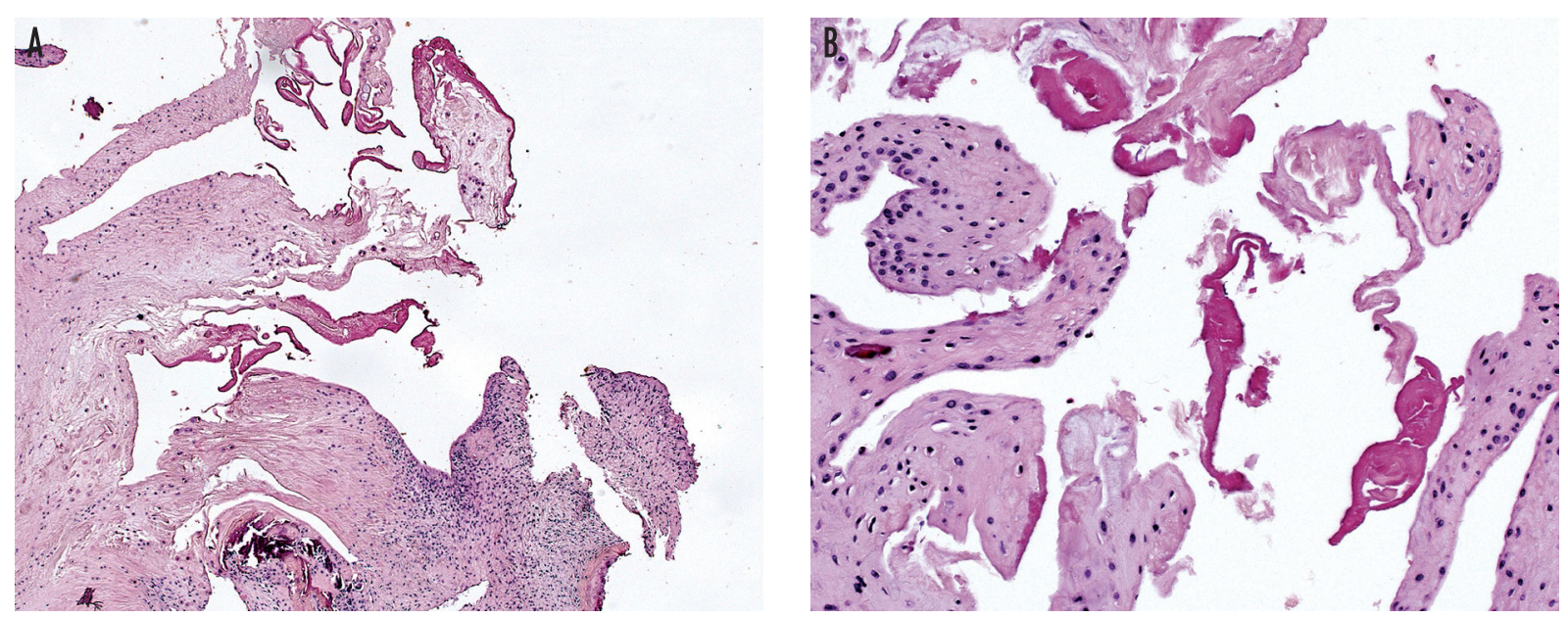

Fig. 2. Pieces of a thick-walled synovial cyst. Fibrous wall shows areas of chondroid metaplasia. Synovial cells forming cyst cavity are clearly visible under higher magnification. H\&E stain. Magnifications: $25 \times(A)$ and $400 \times(B)$, respectively

tissue or dystrophic calcifications in the cyst wall occurred as well (Fig. 2).

Immediately after surgery, all of the patients reported pain reduction; no intraoperative or postoperative complications were reported.

All of the patients were followed with imaging studies performed at least one year after surgery. Functional X-rays showed no postoperative instability. Followup MRI (3 patients) and CT (1 patient) proved complete removal of the cysts (Fig. 3). Pain subsided in 9 cases $(86 \%)$, and sciatica receded in 10 patients (91\%). Neurological deficits withdrew completely in 5 patients (83\%). All of the patients were independent, although 2 of the patients complained of pain that responded to ad hoc analgesics.

\section{Discussion}

Juxtafacet cysts arise from the zygapophyseal (facet) joint capsule. Theories that explain their origin are still controversial, though. The majority of synovial cysts are thought to follow osteoarthritis in the facet joint. There is also general agreement that excessive mobility of the zygapophyseal joint might result in synovial membrane herniation outside an injured joint capsule. This theory is confirmed by the fact that the most common location of synovial cysts parallels the level of the highest spinal mobility, i.e. the L4-L5 segment [1-3]. In our group, 9 out of 11 patients had cysts at the L4-L5 level.

Synovial cysts are usually found in patients in their sixties or seventies, more often in men than women [3]. In our group, most of the patients were in the sixth decade of life and women predominated.
Neurological symptoms in the lumbar spine are related to the degree of spinal root compression. The patient usually complains of chronic local pain or sciatica. Sporadically hypoesthesia or lower extremity paresis occurs [8]. We found hypoesthesia and lower extremity paresis in six patients.

Intracystic hemorrhage might precipitate acute backache, either diffuse or sciatic, aggravate preexisting chronic pain or cause neurologic deficits [9]. Four patients in our group presented with an acute onset of symptoms. Wang et al. [10] point out that hemorrhage might result from increased vascularization of the cyst caused by proangiogenic factors released from the degenerated facet joint. Sometimes the onset of symptoms may be related to injury or strain [11-14]. One of our patients suffered a lumbosacral spine injury.

Both CT and MRI allowed preoperative diagnosis. $\mathrm{CT}$ was performed in 6 patients in our cohort and revealed a cystic structure adjacent to the facet joint, often with calcifications in the capsule. The MR image of the synovial cysts was heterogeneous as the magnetic signal spectrum depends on the heterogenic content of the cyst. Synovial cysts with clear, serous liquid have an isointense signal in T1-weighted images and a hyperintense one in T2-weighted images [1-3]. All of our patients had spinal MRIs performed. Axial images provided superior visualization of synovial cyst location within the spinal canal when compared to sagittal ones.

A synovial cyst that destroys the zygapophyseal joint may also result in degenerative spondylolisthesis. Coexistence of spondylolisthesis with juxtafacet cyst was reported in $38 \%$ to $75 \%$ of cases $[2,9,13,14]$. Accordingly, preoperative diagnosis should include functional 

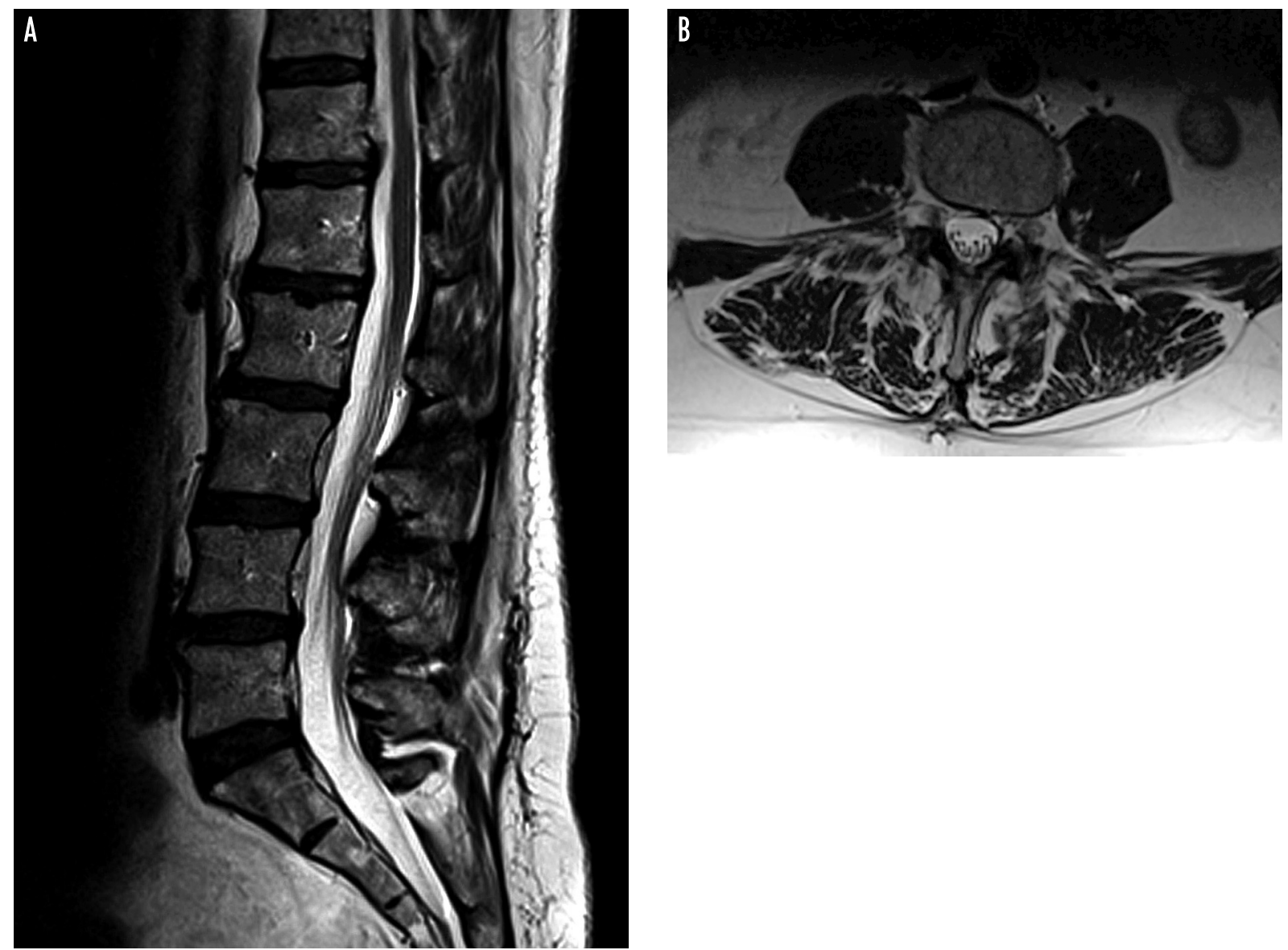

Fig. 3. T2-weighted MR images of the lumbosacral spine performed 12 months after the surgery. Complete resection of the synovial cyst seen in the sagittal (A) and axial (B) planes

X-rays in order to evaluate spinal stability. None of our patients showed any signs of instability.

Synovial cysts should be differentiated with ganglion or extradural arachnoid cysts [12]. Differential diagnosis should also include intervertebral disc sequestration in the spinal canal, central stenosis or recess stenosis related to the facet joint and ligamenta flava hypertrophy. The presence of meningioma or neurofibroma should be ruled out as well $[8,15,16]$.

The therapeutic protocol should always begin with conservative treatment for there is a possibility of spontaneous regression of a synovial cyst [17-19]. Conservative treatment includes steroid injections into the facet joint or epidural space, needle biopsy of the cyst under CT guidance, injections of local anesthetics or steroids into the vicinity of facet joints, acupressure or lumbosacral spine immobilization with an orthopedic corset $[8,20,21]$.

Patients with chronic pain, who failed conservative treatment and presented with neurological deficits such as hypoesthesia or lower extremity paresis were qualified for surgery. Clinical symptoms closely correlated with imaging studies in all of the patients who were qualified for surgery. Surgical treatment involves radical dissection of the synovial cyst approached via fenestration, laminectomy or hemilaminectomy $[1,3,9,13,14]$. Minimally invasive microsurgical and endoscopic techniques are also applicable $[22,23]$. Our microsurgical approach ensured radical dissection of synovial cysts in all of the patients while reducing perioperative injury; it facilitated safe decompression of nervous structures of the spinal canal and preserved spine stability.

Selected cases with preexisting or surgery-related instability require internal stabilization of the spine [1,2]. Khan et al. [3] implemented internal stabilization in 26 out of 39 cases treated surgically due to intraoperatively confirmed instability.

Very good outcomes of surgical treatment are reported in $72 \%$ to $100 \%$ of cases $[1-3,7,9,12,14]$. Followup in our cohort confirmed complete pain decline in 
9 patients and partial in another 2. Complications rarely exceed $2 \%$ and include dural tear, nerve root injury, epidural hematoma, wound infection and deep vein thrombosis $[7,14]$. Recurrent cyst was found in $2 \%$ of patients in follow-up neuroimaging studies [24].

\section{Conclusions}

1. Surgical treatment of spinal synovial cysts is safe, efficient and permanent.

2. Patients whose clinical symptoms correlate with the CT/MR image of the cyst and who failed conservative treatment qualify for surgery.

\section{Disclosure}

Authors report no conflict of interest.

\section{References}

1. Banning C.S, Thorell W.E., Leibrock L.G. Patient outcome after resection of lumbar juxtafacet cysts. Spine 2001; 26: 969-972.

2. Epstein N.E. Lumbar synovial cysts: a review of diagnosis, surgical management, and outcome assessment. J Spinal Disord Tech 2004; 17: 321-325.

3. Khan A.M., Synnot K., Cammisa F.P., et al. Lumbar synovial cysts of the spine: an evaluation of surgical outcome. J Spinal Disord Tech 2005; 18: 127-131.

4. Fonoff E.T., Dias M.P., Tarico M.A. Myelopathic presentation of cervical juxtafacet cyst: a case report. Spine 2004; 29: E538E541.

5. Graham E., Lenke L.G., Hannallah D., et al. Myelopathy induced by a thoracic intraspinal synovial cyst: case report and review of the literature. Spine 2001; 26: E392-E394.

6. Cheng W.Y., Shen C.C., Wen M.C. Ganglion cyst of the cervical spine presenting with Brown-Sequard syndrome. J Clin Neurosci 2006; 13: 1041-1045.

7. Trummer M., Flaschka G., Tillich M., et al. Diagnosis and surgical management of intraspinal synovial cysts: report of 19 cases. J Neurol Neurosurg Psychiatry 2001; 70: 74-77.

8. Shah R.V., Lutz G.E. Lumbar intraspinal synovial cysts: conservative management and review of the world's literature. Spine $J$ 2003; 3: 479-488.

9. Radatz M., Jakubowski J., Cooper J., et al. Synovial cysts of the lumbar spine: a review. Br J Neurosurg 1997; 11: 520-524.

10. Wang Y.Y., McKelvie P., Trost N., et al. Trauma as a precipitant of haemorrhage in synovial cysts. $J$ Clin Neurosci 2004; 11: 436-439.

11. Eck J.C., Triantafyllou S.J. Hemorrhagic lumbar synovial facet cyst secondary to anticoagulation therapy. Spine J 2005; 5: 451 453.

12. Kao Ch.C., Uihlein A., Bickel W.H., et al. Synovial cyst of spinal facet. Case report. J Neurosurg 1974; 41: 372-376.
13. Onofrio B.M., Mih A.D. Synovial cysts of the spine. Neurosurgery 1988; 22: 642-647.

14. Lyons M., Atkinson J.D., Wharen R.E., et al. Surgical evaluation and management of lumbar synovial cysts: the Mayo Clinic experience. J Neurosurg 2000; 93 (1 Suppl): 53-57.

15. Ustuner E., Tanju S., Dusunceli E., et al. Synovial cyst: an uncommon cause of back pain. Curr Probl Diagn Radiol 2007; 36: 48-50.

16. Kobayashi S., Takeno K., Uchida K., et al. Pathogenesis of the discal cysts communicating with an adjacent herniated disc. Histological and ultrastructural studies of two cases. Joint Bone Spine 2010; 77: 184-186.

17. Ewald C., Kalff R. Resolution of a synovial cyst of the lumbar spine without surgical therapy: a case report. Zentralb Neurochir 2005; 66: 147-151.

18. Houten J.K., Sanderson S.P., Cooper P.R. Spontaneous regression of symptomatic lumbar synovial cysts. Report of three cases. $J$ Neurosurg 2003; 99 (2 Suppl): 235-238.

19. Mercader J., Gomez J.M., Cardenal C. Intraspinal synovial cyst:diagnosis by CT. Follow-up and spontaneous remission. Neuroradiology 1985; 27: 346-348.

20. Abrams S.S., Wood G.W., Eames F.A., et al. CT-guided needle aspiration biopsy of an intraspinal synovial cyst (ganglion): case report and review of the literature. AJNR Am J Neuroradiol 1998; 9: 398-400.

21. Cipri S., Cafarelli F., Ielo A., et al. Microsurgical approach to lumbar synovial cysts. Technical notes. J Neurosurg Sci 2004; 48: 29-36.

22. Ishii K., Matsumoto M., Watanabe K., et al. Endoscopic resection of cystic lesions in the lumbar spinal canal: a report of two cases. Minim Invasive Neurosurg 2005; 48: 240-243.

23. Bydon A., Xu R., Parker S.L., et al. Recurrent back and leg pain and cyst reformation after surgical resection of spinal synovial cysts: systematic review of reported postoperative outcomes. Spine $J$ 2010; 10: 820-826.

24. Sabo R., Tracy P., Weinger J. A series of sixty juxtafacet cysts: clinical presentation, role of spinal instability, and treatment. $J$ Neurosurg 1996; 85: 560-565. 